Rodríguez-García, Dan (2006) “Mixed Marriages and Transnational Families in the Intercultural Context: A Case Study of African-Spanish Couples in Catalonia, Spain", Journal of Ethnic and Migration Studies 32(3): 403-33. URL: http://dx.doi.org/10.1080/13691830600555186 


\title{
Mixed Marriages and Transnational Families in the Intercultural Context: A Case Study of African-Spanish Couples in Catalonia
}

\begin{abstract}
One of the consequences of international migration and the permanent settlement of immigrants in southern EU countries is the growing number of inter-country marriages and the formation of transnational families. Using both quantitative and qualitative data, this article examines patterns of endogamy and exogamy (i.e. marriage within/outside a particular group or category) among African immigrants in Catalonia, focusing on bi-national Senegalese- and Gambian-Spanish couples. Sociodemographic profiles, transnationality, the dynamics of cultural change or retention, and the formation of transcultural identities are explored. The evidence presented suggests that social-class factors are more important than cultural origins in patterns of endogamy and exogamy, in the dynamics of living together and in the bringing-up of children of mixed unions. Such a conclusion negates culturalists' explanations of endogamy and exogamy while, at the same time, emphasising the role of social actors as active subjects in these processes. I further argue that mixed couples and their offspring deal-to a greater or lesser extent-with multiple localisations and cultural backgrounds (i.e. here and there), rather than experiencing a 'clash between two cultures'. Therefore, it would be a mistake to pretend that multicultural links do not exist and that they cannot be revitalised and functional. The paper starts and ends by addressing the complexities of processes of interculturalism, resisting an interpretation of hybridity and segregation as contradictory or exclusive realities.
\end{abstract}

Keywords:

Immigration; Spain; Africa; Mixed Marriages; Transnationalism; Hybridity; Interculturalism; Social Incorporation

\section{Acknowledgements}

This article draws on and further develops material from the author's PhD thesis in Social and Cultural Anthropology at the Autonomous University of Barcelona (Rodríguez García 2002; see also Rodríguez García 2004 for a published summary). The research was supported by a Batista i Roca scholarship (CIRIT, Autonomous Government of Catalonia, 1997-98), a BE scholarship (DURSI, Autonomous Government of Catalonia, 2000), and two Fundació Jaume Bofill (Barcelona) scholarships (2000 and 2001-02). It also benefited from the government-funded project 'El dominio teórico transcultural de la procreación' (2002-03) of the Group for the Transcultural Study of Kinship (Autonomous University of Barcelona), of which I am a member. I gratefully acknowledge all funding received. 


\section{Introduction: Context and Preliminary Theoretical Considerations}

The increase in international immigration and new processes of interculturalism in Spain, and in the countries of southern Europe in general (see King 2001), make for some important socio-political challenges. One of the less researched but fundamental aspects of the settlement and accommodation of immigrants in receiving countries is the relationship between migration and lifecycle, particularly with respect to the formation of the couple and the family, and including processes of endogamy and exogamy. While bi-national marriages, ${ }^{1}$ the intergenerational dynamics of sociocultural change, and the formation of multi- and transcultural identities are growing realities in an increasingly globalised world, research on immigration and the social incorporation or accommodation of immigrants is rarely accompanied by treatment of the internal dynamics of interethnic relations. Moreover, unlike in countries such as the United Kingdom, France, the USA and Canada, only recently has study of these phenomena started in the 'new immigration' countries of southern Europe. Thus, much remains to be done regarding the dynamics of interculturalism here, not to mention the processes of assimilation and segregation and the 'politics of belonging' (Favell and Geddes 1999) of immigrants and their descendants.

Spain can be considered a 'new' country of immigration. Its legislation on immigration is relatively recent -the first immigration law (Ley Orgánica de Extranjería 7/1985) was passed in 1985-and still undeveloped with respect to the design of a comprehensive policy of immigration. The priorities of the Spanish government concerning immigration match those of the European Union-from the Schengen Treaty of 1985 and the Maastricht Treaty of 1992-in emphasising the control of flows, while disregarding access to citizenship and the integration of resident immigrants. Indeed, the vagueness of the concept 'integration' points to the limitations in access to civil rights. In brief, the 'integration model' in Spain is closer to assimilation than to pluralistic integration, even though Spain is one of the most plural European countries in terms of the composition of its autonomous regions. Despite the slow start, however, since the early 2000s immigration has featured strongly on Spain's political agenda, making it clear that the issue is no longer just a technical and administrative concern. $^{2}$

It is widely recognised that Catalonia ${ }^{3}$ has a more developed policy of immigration than does the rest of the state, a policy which emphasises mutual dialogue and accommodation beyond the control measures. It tries to reach a consensus on the so-called 'vía catalana d'integració' (Catalan way of integration), a model that wants to be something other than multiculturalism or assimilation: in other words, like the Canadian Québécois, it focuses on language acquisition and education as elements of integration and identification with the territory (see Generalitat de Catalunya 2005). It has been said that Catalonia has always been an immigrant reception region, and that immigration has been an integral part of the 'modern Catalan system of reproduction' (Cabré 1999). The result has been a continuous mixing, although this mixing has been interpreted in very different ways. For example, in the mid-1930s, Vandellós (1935), influenced by the work of the Italian statistician,

\footnotetext{
${ }^{1}$ I will be using the terms 'intermarriage' and 'mixed marriage' as equivalents for 'bi-national marriage', since these terms are commonly used in the European and American literature on migration and ethnic relations. However, it bears mentioning that these notions (and corollary terms of hybridity, etc.) are contested concepts, especially in their meanings as social constructs; my lack of specific reference to such contestation does not imply that the terms are unproblematic or naturalised. See, for instance, Ifekwunigwe (1999: 17-22); Phoenix and Owen (2000: 73, 92); Rodríguez García (2002: 17183); Root (1996: 7-14); Tizard and Phoenix (2002: 7-12, 50-2). See also García Canclini (1995) and Olumide (2002).

${ }^{2}$ For a recent report on the policy debates and legislation on immigration in Spain, see Zapata-Barrero (2003).

${ }^{3}$ Catalonia is one of the 17 autonomous communities that constitute Spain. Catalan was officially recognised as a nationality in the Catalan Statute of Autonomy enacted in 1979 pursuant to the Spanish Constitution of 1978, the culmination of the Spanish transition from dictatorship to democracy. In Spain, Catalonia is, together with Madrid, the region with the highest number of migrants, and in the Mediterranean context it is considered to be potentially one of the main reception areas of international migration.
} 
demographer and fascist theorist Corrado Gini, warned of the dangers of immigration - then coming from the south of Spain-and specifically of the impact of 'poorly directed' amalgamation on the Catalan people:

The purer an ethnic group remains, the more likely it is to disappear. ... However, we need to be cautious about mixing and the assimilation of immigrants. ... For us it would be satisfactory that, in full decline, forced to turn to foreign blood, mixing should bring us, in a relatively short period of time, a rebirth of our ethnic group. ... Although it would satisfy us much more if the Catalans would have more children. ... Because the idea of replacing our people by a new people, having more or less assimilated our culture, always supposing that there were no obstacles to assimilation, awakens a good deal of apprehension (Vandellós 1935: 206-7).

Fortunately, discourse on hybridity (i.e., miscegenation and socio-cultural syncretism) has changed. Jordi Pujol, former President of the Autonomous Government of Catalonia, says:

It is very important that people should mix! It may be that with some of the migrations that we are now seeing mixing may be more difficult. In Catalonia we have always opted to mix: people should having dealings with each other, people should marry, people should, then ... it creates a new reality founded on all of the components present in society. ${ }^{4}$

Indeed, in Catalonia the proportion of mixed marriages (i.e. between people of Spanish nationality and those of foreign nationality) was 12.2 per cent in 2003, three times the percentage of marriages in which both partners were of foreign nationalities. In comparison to 2000, the increment has been of 6.8 per cent (Fundació Jaume Bofill 2005: 232-40, summarising data from the Catalan Institue of Statistics), a fact noted by the media (see Herrscher and Merino 1999). This is also the pattern in the rest of Spain. ${ }^{5}$

Métissage is frequently used as a synonym for a society without differences. In my view this is too simplistic, and it is necessary to analyse interculturalism (i.e. the interactive process of living together in diversity) as a complex space in which the processes of hybridity and segregation, globalisation and localisation, change and retention, coexist and are not necessarily incompatible (Geanâ 1997). Traditionally, demographic convergence in marriage and kinship patterns has been treated as a direct indicator of the integration or assimilation of the immigrant population, presupposing that it implies the absence of ethnic and racial prejudices and that it is the last step in a series of cultural and

\footnotetext{
${ }^{4}$ Extracted from the Jornada Immigració i Política, Auditori de l'àgora Jordi Rubió i Balaguer de la Universitat Pompeu Fabra, Barcelona, 31 October, 2001. Author's own recording and transcription. However, discourse on the 'dangers' of denaturalisation of the native Catalan population reappears time and again. In October 2003, during the Catalan autonomic political campaign, Jordi Pujol and his successor, Artur Mas, representing the nationalist conservative party (CiU), encouraged the increase of natality, within a context of increasing foreign immigration, in order to avoid 'the end of Catalonia' as a nation. In August 2004 a similar public declaration by Jordi Pujol resurrected a social and political controversy. He stated that 'integration doesn't mean amalgamation, which would lead to the end of Catalonia' (EFE 2004).

${ }^{5}$ For the rest of Spain, data provided by The Home Affairs Ministry (2003a: 80-2, 525-41) for 2001 recorded that 11,754 Spanish nationals married foreigners -5.6 per cent of total marriages $(208,257)$-an increase of 1 per cent over 2000 figures. In terms of place of origin, Spanish men- 55 per cent of those in mixed marriages-married Latin Americans (56.9 per cent), followed by EU citizens (14.6 per cent) and citizens from the rest of Europe (14.4 per cent). The largest group of foreign women married to Spanish men was Columbian (21.1 per cent), followed by Brazilians (7.5 per cent), Moroccans (6.9 per cent) and Ecuadorians (5.8 per cent). In 2001, almost half of Spanish women in the survey married citizens of the European Economic Area (41.5 per cent), followed by Latin Americans (23.9 per cent) and Africans (17.9 per cent). Foreign men marrying Spanish women were Moroccan (10.0 per cent), British (8.5 per cent), Italian (7.4 per cent), French (7.2 per cent), and Germans (6.5 per cent). The majority of foreigners who did not marry Spanish nationals married persons of their own national origin. The groups from China, Pakistan and the Philippines appear to be the most endogamous. Provisional data (INE 2005a) for 2004 show that 10.4 per cent of total marriages in Spain $(215,322)$ were between nationals and nonnationals, with Spanish men and women accounting for 58 and 42 per cent respectively. The increase in female migration from Latin American and East European countries in the last few years may also mirror the increase of mixed marriages between Spanish men and Latin American and East European women.
} 
structural assimilations. In fact, the assimilation perspective, widely taken by anthropologists, sociologists and demographers since the 1950s (Banton 1955; Gordon 1964), has argued for assimilation as a 'single final destination' (Todd 1994). In this context, endogamy has been interpreted as a 'traditional behaviour', an 'act of defensive structuring' or an 'anti-integratory' element that limits pluri-ethnic integration and maintains differences-as opposed to exogamy, which causes them to disappear (Coleman 1994). Alternatively Bauböck (1996: 96), McDaniel and Tepperman (2000: 83) and Richmond (1988: 109), among others, have argued that immigrant populations and ethnic minorities tend to maintain patterns of residential concentration and of endogamy largely because of the individual's lack of protection during the initial phases of immigration: this in turn leads to the creation of a social network of mutual support. Furthermore, Myles and Hou (2002: 6) have stated that 'ethnic or racial minorities may choose to live together to gain social, cultural or economic benefits associated with continued co-residence beyond those associated with the initial transition period of immigrant adaptation and acculturation'. They thereby differentiate between immigrant enclaves (neighbourhoods formed by low-income recent immigrants, ethnically and socio-economically homogeneous, where segregation is forced), ethnic communities (neighbourhoods formed by wealthier immigrants, more ethnically homogeneous and more economically heterogeneous and self-segregated), and ethnic ghettoes (neighbourhoods which result from majority exclusion and ethnic communities produced by self-segregation). Hence, not all types of segregation have the same causes or the same meanings.

Given this, one should take into account the multifaceted nature of integration and assimilation processes. As opposed to the traditional straight-line assimilation, which assumes that the best strategy for the social mobility of the second generation is the acceptance of the values and work models of the mainstream, Portes, Zhou and Rumbaut (Portes and Zhou 1993, 1994; Rumbaut and Portes 2001; Zhou 1997), among other migration scholars (see also Alba and Nee 1997, 2003; Brubaker 2001; Kim and Hurh 1993), have developed the concept of 'segmented assimilation' to account for the variable outcomes of processes of incorporation amongst the second generation in the USA. The tripartite model includes acculturation and integration into the white middle class (seen as the outcome for descendants of European migrants), downward social mobility and assimilation into the underclass (Haitians in New York City and Mexicans in Los Angeles are two recent examples), or rapid socio-economic success along with a deliberate preservation of ethnic membership and values and community attachment (Sikhs in the United Kingdom, Chinese and Koreans in Los Angeles and Chicago). Ultimately, the type of assimilation will depend on several factors: origin and duration of residence, age, education level, social class, social interaction, community networks, political context, labour market conditions, etc. In this context, as pointed out by earlier studies (Lievens 1999: 717), intermarrying does not necessarily have to be thought of as an act of modernity; nor is ethnically homogeneous marriage a sign of 'traditional' behaviour (dying out). In other words, immigrants can marry endogamously to satisfy 'modern' goals. Moreover, as Bastide's (1961) classic study, and other more recent works (Fu 2001) suggest, hybridity does not mean a lack of ethnic and racial prejudices, or political and socio-economic structural incorporation (Miles 1993: 173, 177). A cautious approach is advisible, then, when considering a direct relationship between structural, cultural and identity incorporation.

Unlike assimilation (i.e. conformity, unilateral full transition of the minority group to the mainstream society), integration suggests a bilateral process of accommodation whereby majority and minority accommodate to each other (Bauböck 1996). Hybridity is not a sign of integration if, for example, an immigrant marries a national because the government has obstructed a reunion with his or her spouse. $^{6}$ So an increase in the volume of mixed marriages could be partly explained by a restrictive

\footnotetext{
${ }^{6}$ As previously noted, immigration policies in Spain are still fairly restrictive. Accordingly, family reunification is quite constrained. Rather than a fundamental right, it is used as a concession. Further, it depends on other socio-economic factors, such as work and residence status and housing, to which access is also limited. Moreover, the bureaucratic process
} 
legal framework for settlement migration, therefore making it necessary to differentiate between the effects and the causes of assimilation with respect to intermarriage. In my view, then, social integration (versus social exclusion) refers primarily to the structural and instrumental aspects of immigrant inclusion into the host society, such as access in conditions of equality to the rights of citizenship-civil, political and social (Marshall 1950)-and including such social and economic resources as education, health-care work, housing, participation in political life, and the right to family reunification.

\section{The Study and the Sample}

This article is based on a programme of research conducted between 1994 and 2002 in Catalonia, the United Kingdom and The Gambia, the culmination of which was my doctoral thesis (Rodríguez García 2002). In this paper, however, I shall be focusing mainly on field data I collected in Catalonia during 2000 and 2002.

This research incorporated both ethnographic and quantitative methods. Qualitative research was based on participant observation, and included interviews with representatives of several immigrant associations and of local administration. A total of 53 interviews ( 22 thematic and 31 semi-structured in-depth interviews) were conducted, recorded and transcribed. Semi-structured interviews lasted for an average of three hours, and were structured in two parts. The first part compiled biographic and socio-demographic information on the individual, and on his/her partner, parents, siblings, and children - up to four generations - concerning their unions and patterns of endogamy/exogamy: age, birthplace, ethnic group, religion, occupation, place of residence, education level, kin relationship, number of children, etc. This information was later used for genealogical analysis. Family diagrams (31) provided information on 320 unions and 556 individuals. These diagrams were useful to clarify textual information, particularly with respect to diachronic (longitudinal) analysis. The second part of the semi-structured interviews focused on endogamy and exogamy attitudes and behaviours. It included such questions as: How, when and where did you meet your partner? Would you marry/have informal intimate relationships with a person from another country, ethnic group, religion, social class? Would you accept/support your sons or daughters to marry a person from a different country, religion etc? Which are the positive and negative aspects of intermarrying (also for their children)? ${ }^{7}$

Quantitative research in Catalonia included a survey of a non-probability (quota and snowball) sample of 251 individuals, of whom 184 (73 per cent) were Senegalese or Gambians (58.7 per cent were men and 41.3 per cent women). Fourteen per cent were born in Spain (mostly women), and the rest in other African countries, namely Guinea Conakry, Morocco, Mali, Guinea Bissau, Equatorial Guinea and Cameroon and, to a lesser extent, Latin America and the Philippines (mainly women). The questionnaire contained 51 variables, and collected information about the individual and his or her unions. It included place of birth, age, year of arrival, legal situation, religion, ethnic group, marital status, number and type of all unions, offspring, education level, place of residence, occupation, salary, etc. Data were processed with SPSS software, in order to conduct multivariable analysis. In addition, the research included census data analysis, with two main sources analysed: the Census of Population of Spain 1991 and the Statistics of Population of Catalonia 1996. It must be said, however,

for family reunification is easier for certain nationalities (i.e. Latin-American immigrants) than for others (e.g. African immigrants), according to the immigration quota system, which favours the arrival of immigrants with similar social and cultural characteristics. For detailed information on the regulations of family reunification in Spain, see Home Affairs Ministry (2003b: Título I, Capítulo II).

${ }^{7}$ It must be borne in mind that there are differences in the stages reached by different migrant communities in the immigration cycle in Spain. Senegalese and Gambian children are in general much younger than, for example, second- or even third-generation Moroccans, since the former have a more recent presence in Spain. 
that this stock data did not provide information on bi-national marriages. Hence, data were also analysed crossing the information for each nationality and sex group, in order to find the nationality and country of origin of spouses.

\section{Senegambian Immigration to Catalonia}

By the late 1970s, Spain had started to change its traditional trend of emigration-first to the Americas and later to Western Europe - to become a country of immigration. Foreign immigration to Spain increased steadily, originating mainly in European countries, South America, USA and Japan, but also including unskilled workers from Morocco and sub-Saharan Africa. ${ }^{8}$ Because of traditional colonial links and geographic proximity, the Moroccans are still the largest African community in Spain. But since the early 1980s, West Africa-and mainly the Gambia and Senegal-has become an ever-increasing point of origin, to the extent that at present these are the two major sub-Saharan nationalities living in Spain, where they have a particular concentration in Catalonia. As shown in Table 1, at the end of 2003 they accounted for 65 per cent of the total sub-Saharan immigration to Catalonia, and 42 per cent of the number living in Spain overall.

Table 1. Legally-documented African residents in Catalonia and Spain, 31 December 2003

\begin{tabular}{lrrc}
\hline Nationality & Catalonia & Spain & \% in Catalonia \\
\hline Total foreign residents & 383,938 & $1,647,011$ & 23.3 \\
Total Africa & 147,288 & 432,662 & 34.0 \\
North Africa & 124,366 & 3654,385 & 34.0 \\
Morocco & 117,752 & 333,770 & 35.2 \\
Sub-Saharan Africa & 22,922 & 67,277 & 34.1 \\
Gambia & 9,586 & 11,329 & 84.7 \\
Senegal & 5,491 & 16,889 & 32.5 \\
\hline
\end{tabular}

Source: Home Affairs Ministry (2003a); author's elaboration.

There are a number of causes for this migration. Since the 1970s, the region of Senegambia, ${ }^{9}$ and the Sahel in general, has suffered from a process of desertification that has seriously affected its subsistence economy of farming and herding. This coincided with the fact that, since the late 1970s, many countries in the sub-Saharan region have enacted restrictive legislation to regulate the crossing of their frontiers, which has curtailed the possibilities of internal labour mobility. To these environmental and politico-economic push factors should be added the tightening of visa restrictions, which produced a decrease in immigration to northern Europe, not to mention the booming Spanish economy in the late 1970s and early 1980s (after the Franco regime), which created a new demand for a cheap labour force, traditionally provided by internal migrants.

\footnotetext{
${ }^{8}$ Provisional data from Padrón-the Municipal Register Data which include both registrants with and without legallydocumented residence-report, as of 1 January 2005, 3,691,547 foreign residents in Spain, representing 8.4 per cent of the total population (a percentage higher than in Italy, the United Kingdom and France), and 795,800 in Catalonia (the autonomous community with the largest number of foreigners), representing 11.4 per cent of the total Catalonian population. Romanians, Ecuadorians and Chinese have shown the greatest increase, demonstrating a diversification of immigration to Spain (INE 2005b).

${ }^{9}$ Senegal and The Gambia are situated in a south-west region of the Sahel called 'Senegambia', a term already in use by the British in 1765 to refer to the French and British colonial settlements in the region. Senegambia is also the name of the political and economic federation these two countries formed in 1982 and which split in 1989.
} 
In broad terms, the Senegambians living in Catalonia are mostly young male Muslims (most of the population of Senegambia is Muslim) who emigrate from rural origins with the objective of improving their living standards. As economic migrants, they take on the most precarious jobs in agriculture, construction, services and manufacturing, while supporting a large, diversified underground economy, and incipient ethnic and transnational businesses. Despite working in unskilled jobs, a number have high educational attainments. The majority of the men in the sample arrived in Spain during the 1980s, while the women arrived during the 1990s. As pointed out by Kaplan (1998), Senegambian women-especially those who arrived before the 1990s-emigrated fundamentally for the purpose of family reunification, often with a number of years passing before this plan was fulfilled (I registered some couples who waited up to seven years). Nearly 50 per cent of the women in the sample have a permit of residence (not a work permit), and around 30 per cent of those married to Senegambian men resident in Catalonia remain in their domestic place of origin, as guardians of the children and administrators of the domestic economy. Only once the men reach a certain stability as regards employment, legal and residential status, do they begin the process of family regrouping, as illustrated in the following quotes, collected during fieldwork in 2000-02. ${ }^{10}$

I came here because of my husband; yes, he brought me in September 1994. ... First, we married in Senegal, and then to arrange all the papers to come was exasperating. It's very difficult to come, you know? He [her husband] got here first, in 1990; so when he arranged his papeles [legal residence] he went there [Senegal], got married, and want to bring his wife (Absa, 23-year-old Senegalese woman, married to a Senegalese man, with three daughters).

I have [been] in Spain for six years, since 1994. ... A man brought my husband here to work, yes. Après I was in my country, with my two children. Then, my husband had been here for two years, and he arranged paper and brought me here (Khadi, 27-year-old Senegalese woman married to a Senegalese man, with three children).

Nonetheless, in recent years the immigration of women-in general much younger, and emigrating either on their own or to be reunited with their families-has increased. Indeed, the feminisation of migration is a growing trend in Spain and globally (SOPEMI 2004).

Most Senegalese and Gambians are transnational migrants; that is, they maintain multi-dimensional (political, economic, family, cultural) social relations that link their places of origin and places of immigration (Castles and Davidson 2000; Glick Schiller et al. 1995; Portes et al. 1999; Vertovec and Cohen 1999). Initially, the intention of most of those who migrate to Catalonia is temporary migration with the aim of obtaining resources to be invested in their country of origin. The family sees the emigrant son as a saviour: life insurance for parents in countries where the population lives on very slender means. In this sense, emigrating to Europe has become a sort of 'rite of passage' for the youth; in turn, those who get there never describe their bad experiences, thereby feeding the myth of 'paradise abroad'. While they are awaiting sufficient resources to go back, however, return is often delayed indefinitely, turning these temporary migrants into 'permanent' immigrants. As explained by one of the interviewees:

What you want is to be rich, that's the dream inside your head: you want to go back richer than your father, you understand? But what happens? You spend years here, years, years. You want to be rich in order to go back, and you'll never be rich! ... You always want to have twice as much; but it never comes! And one year goes by, and then another. And the years go by and you don't even notice! (Sherif, a 37-year-old Gambian, married to a Spanish woman, with three children).

\footnotetext{
${ }^{10}$ I have translated all interviews, quotations and conversations into English. Although in many cases, my informants spoke imperfect Spanish, Catalan or English, I have not tried to render their imperfections into perfect English. In the quotes I will be using 'Senegalese', 'Gambian' or 'Spanish' to mean country of birth.
} 
In this context, the localisation difference-the 'origin' (homeland) and the 'destination' (host society)-are flexible entities, recreated (partly idealised) and transformed during the migratory process. Here, I suggest, we can not only talk about a 'myth of return' (i.e. the aim of return, eternally delayed) but also about a 'myth of settlement', where a permanent settlement never occurs, either in the society of immigration, or in the society of origin. Figure 1 is my attempt to model these relationships in the context of my field data. The fluidity and dynamism of the processes of transnationalism do not mean, however, that the differences (localisations) disappear or 'do not exist'. Rather, as Grillo et al. (2000) suggest, transnational individuals live in a global context, but form part of particular (trans)local networks and loyalties, where the differences/localisations are constantly transformed and reinvented.

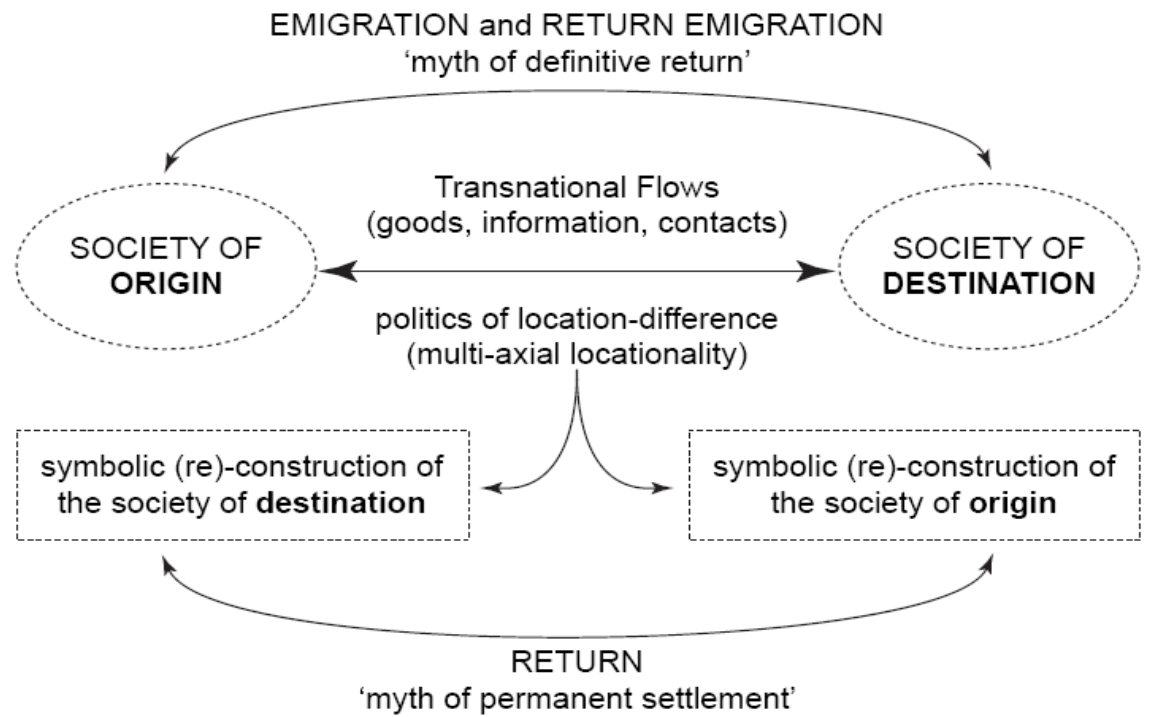

Figure 1. The context of transmigration Source: Author's survey.

\section{The Predominance of Endogamy}

Numerous studies, carried out across a wide range of disciplines, show that the patterns of choice of marriage partner vary least with migration, and that endogamy (marriage within the same group) and homogamy (marriage between individuals of similar socio-economic status) are the predominant trends (Coleman 1983, 1994; Fu 2001; Gray 1987; Kalmijn 1998; Merton 1941; Murstein 1986; Musham 1974; Stark 1988; Varro 1995; Winch 1958). This is congruent with the findings of current research with Senegambian immigrants in Catalonia, at all levels analysed: country and region of birth/upbringing, religious affiliation, ethnic-linguistic group, family (kinship ties) and social class. Figure 2 shows census data on country of birth of spouses of the population of Moroccan, Gambian and Senegalese nationality living in Catalonia. In all cases, the data show the predominance of endogamy by nationality. ${ }^{11}$ Spanish is always seen as the majority nationality in mixed unions. Significantly, the number of unions between Senegambians and Moroccans-and in general between sub-Saharans and Maghrebis-is practically non-existent.

\footnotetext{
${ }^{11}$ Although only data by the spouse's country of birth are shown here, it should be pointed out that the index of endogamy is lower if the variable considered is the nationality of the spouse.
} 

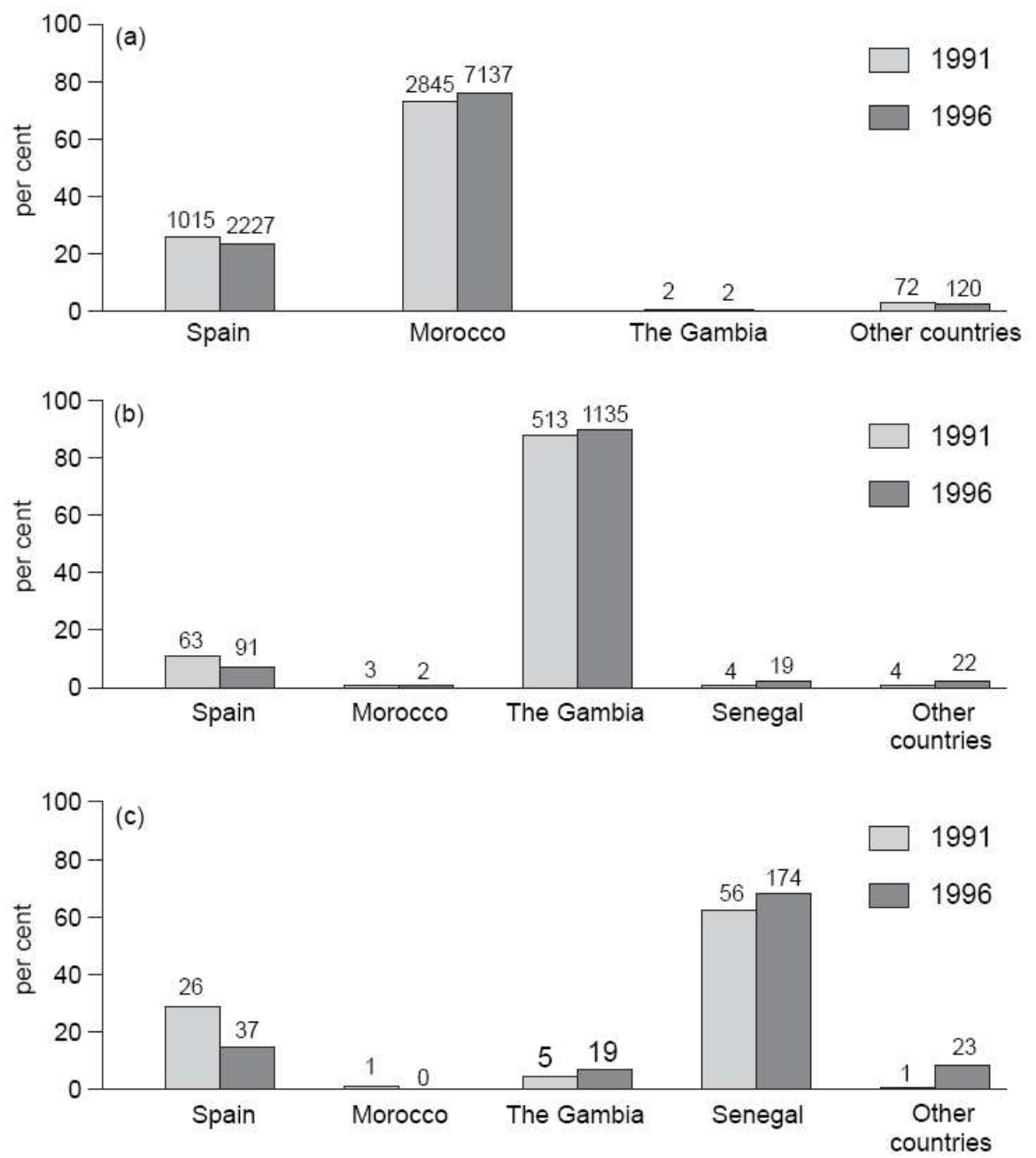

Figure 2. Population of (a) Moroccan, (b) Gambian and (c) Senegalese nationality living with spouse in Catalonia in 1991 and 1996, according to country of birth of spouse (percentages and absolute numbers)

Source: Census of Population of Spain (1991) and Statistics of Population of Catalonia (1996), data from IDESCAT. Author's elaborations. 
As shown in Table 2, there are more African men married to Spanish women than the other way round, both in 1991 and 1996.

Table 2. Population of African nationality living in Catalonia in 1991 and 1996, according to sex and country of birth of spouse

\begin{tabular}{|c|c|c|c|c|c|c|}
\hline & \multicolumn{2}{|c|}{ Men } & \multicolumn{2}{|c|}{ Women } & \multicolumn{2}{|c|}{ Total } \\
\hline & no. & $\%$ & no. & $\%$ & no. & $\%$ \\
\hline \multicolumn{7}{|l|}{ 1991: } \\
\hline Spain & 910 & 63.6 & 520 & 36.4 & 1,430 & 28.1 \\
\hline Morocco & 1,417 & 49.6 & 1,439 & 50.4 & 2,856 & 56.2 \\
\hline Gambia & 258 & 49.6 & 262 & 50.4 & 520 & 10.2 \\
\hline Senegal & 31 & 50.8 & 29 & 47.5 & 61 & 1.2 \\
\hline Other countries & 104 & 47.7 & 115 & 52.8 & 218 & 4.3 \\
\hline Total & 2,720 & 53.5 & 2,365 & 46.5 & 5,085 & 100 \\
\hline \multicolumn{7}{|l|}{ 1996: } \\
\hline Spain & 1,755 & 62.8 & 1,038 & 37.2 & 2,793 & 23.5 \\
\hline Morocco & 3,580 & 50.0 & 3,581 & 50.0 & 7,161 & 60.3 \\
\hline Gambia & 579 & 49.5 & 591 & 50.5 & 1,170 & 9.9 \\
\hline Senegal & 122 & 57.0 & 92 & 43.0 & 214 & 1.8 \\
\hline Other countries & 271 & 50.9 & 261 & 49.1 & 532 & 4.5 \\
\hline Total & 6,307 & 53.1 & 5,563 & 46.9 & 11,870 & 100 \\
\hline
\end{tabular}

Sources: Census of Population of Spain 1991, Statistics of Population of Catalonia 1996; author's elaborations.

This is congruent with my analysis of data for the fieldwork sample, which confirms the predominance of endogamy (see Figure 3). ${ }^{12} \mathrm{~A}$ greater number of Senegambian men tend to marry other nationalities than do Senegambian women. Further, it confirms that there are few unions between Senegambians and Maghrebis, suggesting that affiliation to Islam-shared by the majority of people in both groups-is not so cohesive an element as one might think. Interview narratives reveal powerful reasons for the lack of intermarriage, such as priorising compatibility in the migratory project, differences based on the type of religious practices, the structure of the family and gender roles, and racial and cultural prejudices existing between the two communities.

\footnotetext{
12 In this case, the high percentage of mixed unions results from the type of sampling (quota and snowball). Besides, it is possible that there is an over-representation of endogamy, since the majority of migrants, especially women, have been recruited because they are married (the main reason to migrate is marriage in their country of origin).
} 

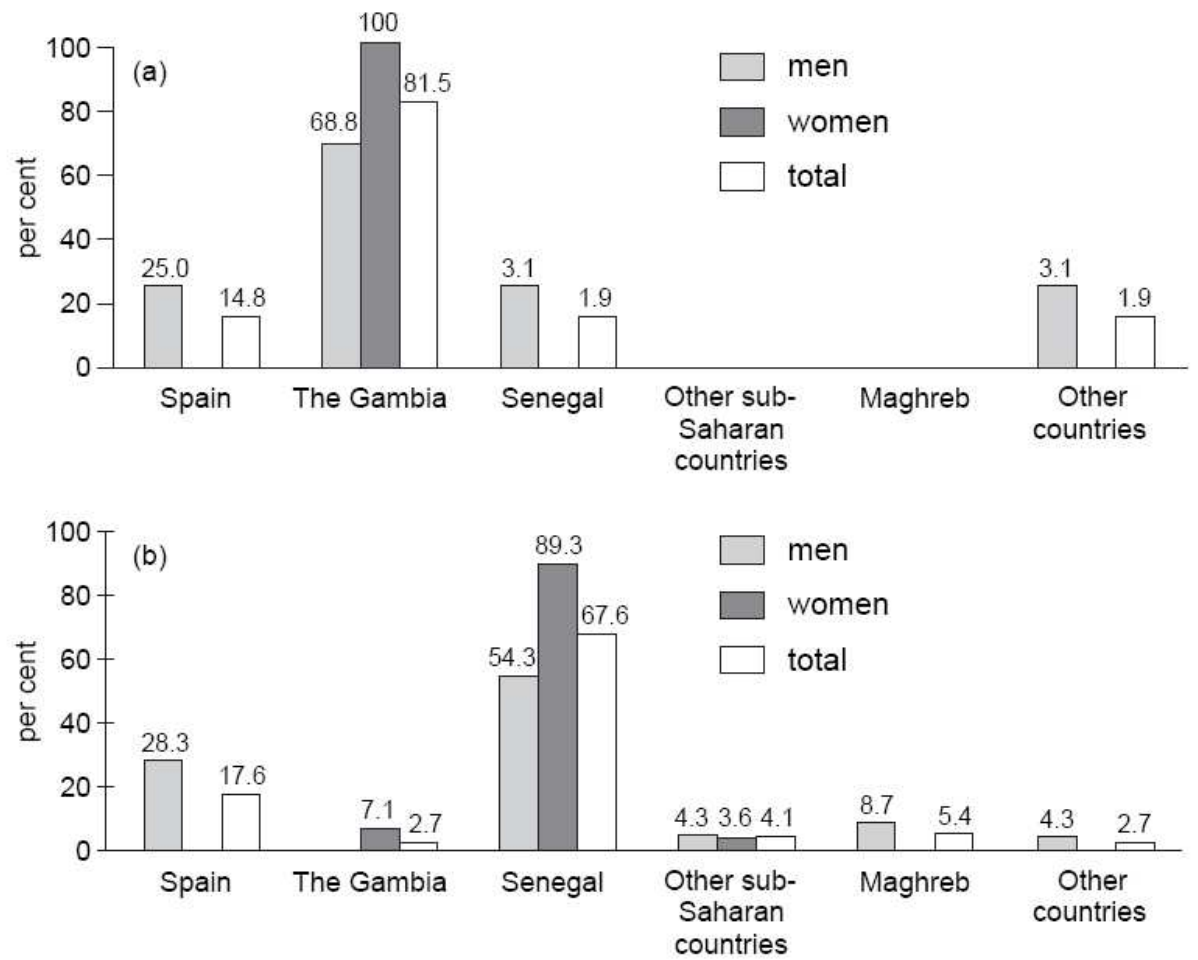

Figure 3. Population born in (a) The Gambia and (b) Senegal living in Catalonia by sex, according to place of birth of spouse or cohabiting partner (\%)

Source: Author's survey data.

Note: $\mathrm{N}=251$.

To be more systematic, the reasons for the predominance of endogamy are preferential, normative and structural. For one thing, it can be explained by the traditional pattern of male migration (with subsequent reunion with the wife) and the goal of temporary migration (with return and investment in the place of origin of the financial and/or educational capital obtained abroad). At the same time, endogamy is an element of group cohesion and of reference within the family organisation; it is the basic means and principle vehicle for the transmission of the values and cultural codes of the society of origin to which return is intended. For structural reasons, Senegambian men are more exogamous than Senegambian women. ${ }^{13}$ The fact that Senegambian men are more exogamous than women is also explained by religion as, according to Islam, Muslim men can marry Muslim, Jewish or Christian women, while Muslim women cannot marry a non-Muslim, as their children are considered kafir or lost to Islam.

The endogamous trend may be reinforced by negative attitudes towards 'miscegenation' in the host society, based on a set of stereotypes and prejudices towards immigrants who come from poor countries (seen as delinquents, opportunists) and, in the case of Senegalese and Gambians, to historically rooted and recreated prejudices and stereotypes based on skin colour: ${ }^{14}$

\footnotetext{
${ }^{13}$ Amongst more feminised immigrant communities, for instance Latin-Americans, there is a higher number of women involved in mixed marriages.

${ }^{14}$ Several studies in Spain confirm these negative attitudes towards mixed marriage relationships with immigrants and visible minorities, especially those of African origin and gypsies (the historical internal 'others'); see for instance Calvo Buezas (2000: 74-5, 186-7). The outbreak of racial discrimination in the neighbourhood of Ca n'Anglada (in the province of Barcelona) in 1999, when Moroccan-Spanish couples experienced particularly harsh judgment, can also be mentioned here (see Rodríguez 1999). It is obvious, however, that a mixed union-in religious, ethnic or 'racial' terms-has not the same implications in Catalonia as in, say, the former Yugoslavia, the Republic of Ireland or Israel, where intermating and, especially, intermarrying has critical social and political implications.
} 
I arrived here and hear: 'nigger', 'coloured'... So then, I thought: 'If I marry a white Spanish woman, I may get in trouble!' You can always find someone who loves you, but what about her environs? Depending on the family, who knows what would happen. So, to avoid all this ... the less trouble the better. ... Nobody likes being in a discotheque with a white woman and people saying things (Amar, 33year-old Senegalese married to a Senegalese woman).

Some people think that women that mate with us are those who cannot find a person who loves them; they might be considered as prostitutes (Lamine, a 40 -year-old Senegalese, cohabiting with a Spanish woman, with one child).

There is a lot of racism. They say: 'How can this black man have that house?'... Society does not admit mixed couples, even if they say they do. I lost most of my friends; I know they dislike me because I am with a black person, as if it said: 'AIDS' or 'drug pusher' (Ángela, a 37-year-old Spanish woman, cohabiting with a Gambian man, with a 5-year-old daughter).

As Meyer and Gestchiere (1999) note, during migration and social incorporation, processes of cultural change and processes of cultural retention or revitalisation both occur. In general, greater connection between the community network of the country of origin and that of the ethnic community in the host society leads to endogamy, while the opposite leads to exogamy. In this sense, young immigrants and the descendants of immigrants tend to be more exogamous than firstgeneration immigrants, because of a breaking of ties with their country of origin or that of their parents, and the consequent diversification of social networks and the possibilities of interaction, as well as the rupture between traditional models and practices and their instrumental meaning (for instance, arranged marriage). On the one hand, as shown in Figure 4, Ego's grandparents, parents and older brothers are married to women born in the same country (The Gambia). In the majority of cases, the two spouses are of the same ethnic group (Serahule) and social status (Tagay or blacksmiths). On the other hand, Ego, the fifth of seven brothers, and his younger brother, both emigrants, are married to non-African women. Nevertheless, as shown in Figure 5 (see Ego), endogamy and exogamy are neither mutually exclusive nor irreversible processes. 


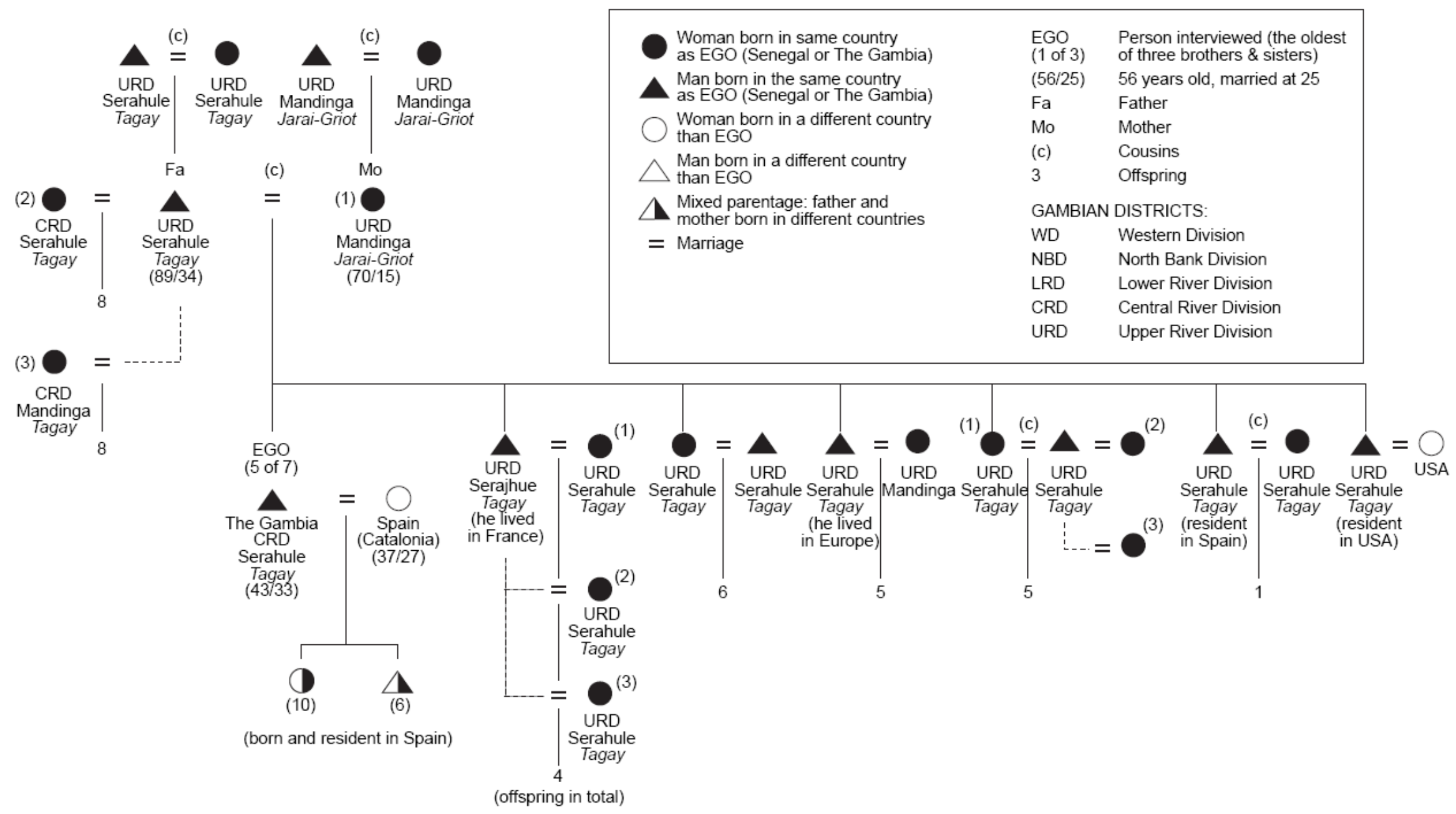

Figure 4. Genealogical diagram, Family 1 Source: Author's survey. 


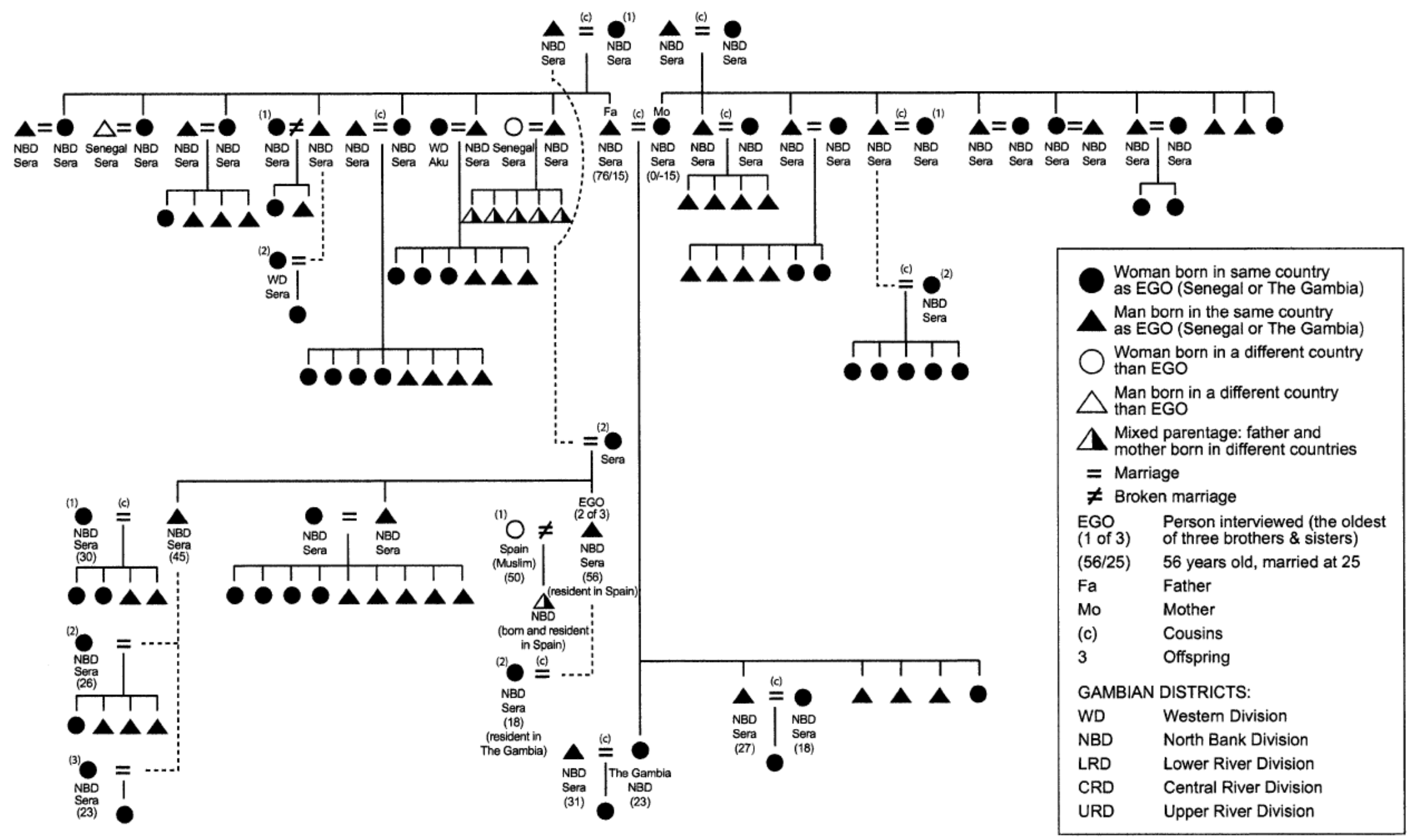

Figure 5. Genealogical diagram, Family 2 Source: Author's survey. 


\section{The Significance of Exogamy: Intermarriage and Transnational Families}

\section{Mixed Unions}

As noted above, for many Senegambians who migrate to Catalonia there is an clash between the initial intention of temporary migration, and the unforeseen reality of 'permanent' settlement. One consequence of this unplanned permanence is mixed unions. In Sherif's words:

I didn't intend to get married here. When I came, I planned to come and work, make some money, and then go back to see my mother and look after her.... Then time goes by, until you meet someone and then you talk and so on and, well, here we are.... There [Gambia], they always look for a wife for you so you can get married, when you're a kid, without you knowing. And you come here to make some money and then go back and then give the money to her family, and then talk to her and get to know her, and then if you can you get married. ... For me it was like I won the lottery. (Sherif, a 37-year-old Gambian, married to a Spanish woman, with three children).

Data from the research sample suggest that most Senegambian men who form mixed unions are either single or have previous relationships that have not been formalised; they also have socioeconomic resources and contacts abroad (chain migration) prior to emigration. Mixed unions tend to be homogamous (both spouses share similar socio-economic status) or, at least, hypergamous ('marrying up') for the Senegambian spouse (Figure 6). Nearly 68 per cent of African-born women and men couples have similar education and professional levels, while 71.4 per cent of African men married to Spanish women have a lower level-although their earnings are similar. Cohabitation mixed unions are chiefly homogamous, and both partners have, on average, higher socio-economic status than those forming mixed marriages.

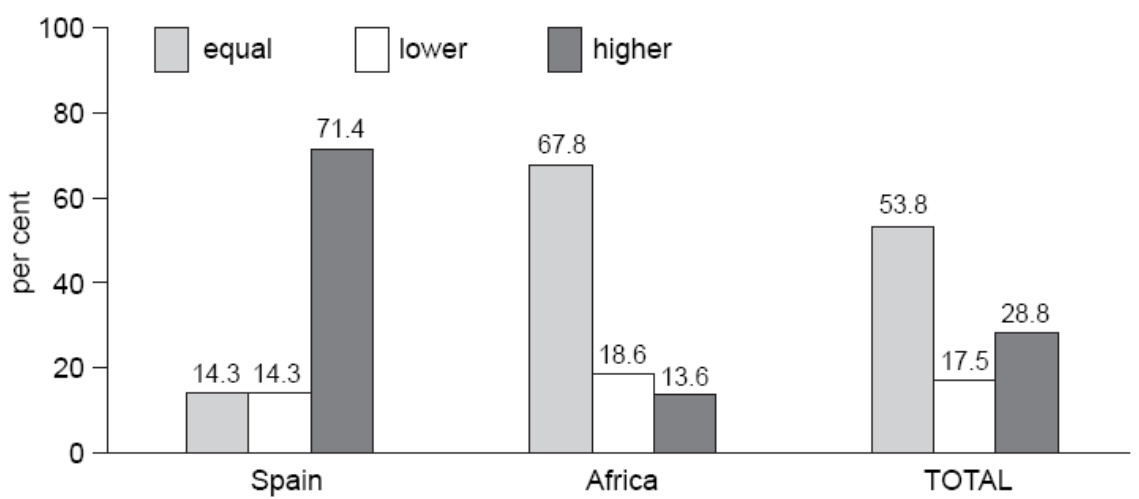

Figure 6. Marriages of Africa-born men, according to the educational-professional background of spouse (Spanish or African) (\%)

Source: Author's survey data.

Note: $\mathrm{N}=251$. 
In this context, so-called 'marriages of convenience', in which the reason for the union is to reduce the period established by law for the acquisition of nationality, are possible. ${ }^{15}$ Some of the interviewees in Catalonia justify marriages of convenience as a means of becoming legal in the host country, in order thereby to improve access to resources and social mobility: ${ }^{16}$

Well, you know: you apply for residence and it doesn't work out, you know? [smiling] And if you meet a girl that can marry you, for sure you're not going to give it a second thought, you know? So as to be legal here. Because I've been in prison here, for not having papeles [meaning legal status]. ... Man, if for example I can avoid that, I'm going to avoid it [laughs] (Abdul, a 32-year-old Senegalese, married to a Spanish woman, with one child).

This is congruent with the narratives of interviewees in their place of origin. As explained by two young men I interviewed in the Gambia:

Yes! Many do so in order to find a way out, to have work and help the family here. ... Mostly men do it, since marrying a white girl means greater opportunities to go to Europe, and then they can work and help their families (Famusa, a 22-year-old Gambian male, single).

Most of them marry [European women] and then come back [to the Gambia]. Yes, they break up and then marry here. Even those who have married in Sweden and so, they divorce and come back and form a family here. (SulaymanBo, a 24-year-old Gambian male, single).

In this sense, bigamy is also possible, the exogamous union in the host country co-existing with one or more endogamous unions in the country of origin (polygamy is recognised by the legal systems of Senegal and the Gambia), something which can easily remain unobserved at official level, as marriage in the country of origin does not normally involve registry procedures.

Strictly speaking, marriages of convenience are not common among the Senegambians living in Catalonia, and are more common among immigrants from Eastern Europe, Russia and Latin America, especially Cuba. ${ }^{17}$ Even so, most of the Senegambians interviewed know about co-ethnics who have married in countries in the north of Europe, where until recently it was relatively easy to obtain 'los papeles' (legal residence, citizenship) through marriage with a citizen. In Samba's words:

I was in Germany; I had women, girls ... lots! ... I had one who was 17, and when she was 18 her mother said to me: 'I want her married', and I said 'No'; and then that was finished right there. ... And she said to me: 'Oh, but lots of blacks get married here to get their papeles, pum pam...' I said: 'That may be, but I don't want to get married for any piece of paper, because I've been going round Europe for years without being married'. ... With her [his Spanish partner] I've been eight years and we're not married. (Samba, a 40-year-old Gambian, cohabiting with a Spanish woman, with one daughter).

\footnotetext{
${ }^{15}$ Currently, in Spain, nationality through residence is obtained after a period of ten years, five for those who qualify as asylum-seekers or refugees, and two if the applicants are nationals of Latin-American countries, Andorra, the Philippines, Equatorial Guinea or if they are Sephardic. Nationality through residence is obtained in one year-among other cases-by those who at the time of application have been married to a Spanish citizen for a year and are not legally or de facto separated.

${ }^{16}$ Spain has an agreement of double nationality only with Equatorial Guinea. Hence, although obtaining Spanish nationality means greater legal facilities for the immigrant, many Senegambians do not ask for it, so that they may keep their former nationality.

${ }^{17}$ Until the 1990s, entering Spain from Cuba was relatively easy. With the worsening of the crisis in Cuba, Spain restricted access to visas, and the volume of mixed 'marriages of convenience' began to grow significantly. The media have echoed this (see Vicent 2001).
} 
It may even happen that 'marriages of convenience' become 'marriages of love':

What happens is that, afterwards, children come and then ... it has to continue. ... Some do not, and get divorced, you know what I mean? It depends on the fortune (Juana, a 43-year-old Spanish woman, married to a Senegalese man, with four children).

One can say: 'I am going to marry to get the papers'. But then, they get catch on [laughs]. What began as a joke becomes the truth (SulaymanGe, a 43-year-old Gambian, married to a Spanish woman, with two children).

In any case, the possibility of obtaining 'los papeles' through mixed marriage is not per se considered the reason for the union:

If you get married here, and have children, it's easier to get papeles. For example, you go to the town hall, you get married, so that you can get your papeles. ... You're going to do it so you can live with your partner, so that you can work. ... You get married first for love, but it's a chance to get your papeles ... (Malick, a 42-year-old Senegalese, married to a Spanish woman, with one child).

Finally, a distinction can be drawn within the sample between two types of mixed couple involving Senegalese- and Gambian-Spanish couples in Catalonia, and coinciding with different moments in time. In brief, on the one hand, in the couples formed in the 1970s and 1980s, the women are principally from the regions of the south and centre of Spain; ${ }^{18}$ many were divorced and had children predating the mixed union, and they generally had the idea of forming a family. On the other hand, more recent couples have generally met through tourism. In these, the women are mostly born in Catalonia, are younger, have a better education, and do not tend to have been previously married. In the latter case, there are more informal unions-with or without cohabitation. ${ }^{19}$

\section{The Dynamics of Hybridity: Socio-Cultural Change and Retention, Conflict and Accommodation}

The context of union formation and the dynamics of mixed unions present a particularly active and complex socio-cultural hybrid space, an 'in-between space' (Bhabha 1994: 1) or 'diasporic space' (Brah 1996: 195, 208) which encompases both the local and the global and in which the differences and identities of ethnic origin, class and gender intersect and are contested. In these interactions, conflict may originate in different socio-cultural customs, such as the so-called 'clash' between the independence of the Western way of life and African family solidarity (i.e. economic help for the family in the country of origin and mutual help between fellow-countrymen in the host society):

Most of those that leave the Gambia have the support of the whole family: your mother, your father, your brothers help you to leave; they give you money, they give you all their support, they prepare the way for you; and then you owe the family! You've got a responsibility to the family. If you come here and in two or three years you've forgotten that, you're just not like your family any more: the relationship has been broken... In mixed couples, there's conflict over that (Alagey, a 46-year-old Gambian, married to a Gambian woman, with five children).

\footnotetext{
${ }^{18}$ During the 1960s and 1970s, Spain experienced an intense migration flow from southern (chiefly Andalusia) to northern provinces. Catalonia was one of the main reception regions.

${ }^{19}$ Although not studied in depth in this article, it must be said that the difference between 'marriage', 'cohabitation' and other forms of short association without cohabitation, has been taken on board in my research. Evidence shows that mixed cohabitation and mixed short-association unions are more frequent than intermarriage, partly because, at a public level, the pressure of the norm is greater. Data from the research sample also suggest that common-law unions are mainly formed by Senegambian men and non-African women (70 per cent of them were Spanish and the rest from other, chiefly Latin-American, countries and the Philippines).
} 
Mbay: Me, if someone rings the doorbell, I go to open the door. ... I can't live without people! If anything happens to me today, people will come today! If they let you leave Africa, you get the money together and send it back to Africa, right?

Juana: I'm not saying anything about that. But what I will tell you is that there are lots that say they're your friends when you've got some; if you've got nothing they see you in the street and don't even say hello.

Mbay: You've seen my house, there's tons of people; when it's time to eat, everyone!

Juana: That's why we're the way we are.

(Mbay, a 50-year-old Senegalese man, and Juana, a 43-year-old Spanish woman, married and with four children).

However, there are contradictions among the Senegalese and Gambians between an overt discourse of solidarity and a covert discourse of autonomy and individuality. Furthermore, conflict does not always arise and, in any case, is lessened if there is flexibility and negotiation on the part of both spouses:

Samba: We used to think, when you come here to Europe, you marry a white woman, you forget your family. ... I say: 'Well, if I marry someone who is a Fula like me, then I'll go on helping my family; if I get me a white woman maybe she won't let me help my family'. But it was the other way round: everything I want, I send it to my family; and even if we've not got any, she helps me find some to send it there. So I say: 'Look, what people said isn't true!'

Ángela: There are morenos [Senegambians] that only live for their family over there and they forget what they've got here; and there are people that even though they're with a white woman, they shouldn't think that we're not going to help.

(Samba, a 40-year-old Gambian man, and Ángela, a 37-year-old Spanish woman, cohabitants with one daughter).

For example, suddenly five friends turn up without having phoned, right? And my wife could get mad, for example. Mais, there in Senegal, never! That's our custom. ... Mais here it's very difficult. I understand it because it's the education you get from when you're a kid. If you show up and we're eating, you have to eat. Here all that's more closed up; mais I understand. Here, I've learnt a lot. It's tough, because I've got my culture, she's got her culture, too. There are things I don't understand about marriage here; but I do it because you have to respect other people's culture. She's respected my culture too: first, she became a Muslim, that's something, isn't it? [So] I've got to respect her too. There are some things that are very hard, but I try (Malick, 42-year-old Senegalese, married to a Spanish woman, with one child).

Hence, differences do not always make for insurmountable obstacles. Rather, where negotiation and mutual accommodation of differences occur, cultural practices are transformed and re-elaborated by the social actors themselves, giving rise to very diverse responses. As SulaymanSa explains, being clear from the beginning is the way to avoid problems in the future:

I don't have to pretend to be another person. This leads to many conflicts among mixed marriages. ... We are from different cultures, so we have to manage it well, always saying the truth. I said to my wife, from the beginning: 'I am Muslim, and I do not eat pork', I said that very clear! 'I do not drink alcohol'. But others keep these things hidden, and then the second generation turns up, that is their children. They are probably going to be raised by your mother-in-law, and you might find your mother-in-law feeding your children with pork ham; so the fight starts: 'Why are you giving pork to my children!' But tell her before, so she and all the family knows, idiot! You can eat ham, I'll have a sardine! And I have problems with nobody (SulaymanSa, a 52-year-old Gambian married to a Spanish woman, with three children).

Another source of conflict is different models of gender relations, that is, between the separation of sexual roles and a trend towards equality of roles. As Abdul explains: 
Women here [Spain] are different than there [Senegal]. For example, in Senegal you have your wife, but you leave the house and come back whenever you want; no problem. ... There men bring the money home, so they do not have to stay at home all the time; they are always out. But here is different: you and your wife, both works. So all the expenses ... all this is different. ... Here there are limits, there, there are no limits [laughter] (Abdul, a 32-year-old Senegalese married to a Spanish woman, with one child).

In this context, socio-cultural change and retention depend on several factors: the migration project, transnational and community ties, work, the socio-ecomonic situation, etc. There are cases where socio-economic precariousness coincides with greater retention of the original cultural practices, but there are also people who, on improving their socio-economic status, and in a situation of greater stability, tend towards cultural revitalisation. Once again, there are multiple responses, meaning that negotiation and adaptation to differences are both desirable and feasible.

The most obvious context in which these dynamics of conflict and accommodation take place is the upbringing of children, specifically in the intergenerational transmission of values and socio-cultural models. In general, the parents try to preserve and transmit their respective values, with more or less flexibility. Senegambian parents resign themselves to their children 'losing their culture of origin', and understand that children, particularly those born and/or brought up in Catalonia, live in another context, with different values and points of reference. On the one hand, Senegambian parents encourage their children to adopt modern ways of doing things, since these skills may help them acquire a good education and employment opportunities. On the other hand, they may feel threatened by their children-especially their daughters-becoming 'too Westernised' in their behaviour in such areas as choice of friendships, sexuality and drinking. By way of contrast, the sociocultural background that Senegambian parents want to transmit to their children has to do with values and customs linked to traditional family dynamics and the affiliation to Islam. As this occurs in a context in which Islam is looked down on socially, it is difficult for immigrants' children-who, like all children, seek acceptance by the majority group-to openly identify themselves as Muslims, and the children of immigrants. As explained by an interviewee:

They are like chameleons until they're sufficiently sure to be able to show it in public. And the fact is that it's really hard to be continually justifying a choice that isn't normal, that people look down on. Here, in countries like Spain, with not many resources, where you can't provide them with a clear alternative, those kids are at risk of being marginalised (Maryam, a 44-year-old Spanish woman converted to Islam, married to a Senegalese man, with two children).

Social rejection of the children because of phenotype leads to similarly adverse reactions:

My daughter says she doesn't want to be black; she says she's 'white coffee', and I tell her: 'You're like your Dad'. And she says: 'No, Dad is black, I'm white coffee'; and she says: 'Couldn't he be more white?'. I don't know why she says that. ... (Ángela, a 37-year-old Spanish woman, cohabiting with a Gambian man, with one daughter aged 5).

Many of the Senegambians interviewed argue that the main obstacle to the transmission of sociocultural values in mixed couples is the fact that the children spend more time with the Spanish mother than with the Senegambian father:

There's a problem, because there are lots that just don't control it ... because, in the first place, hey, the kids just don't know their Dad's culture! They were born here, everything they know is here, nothing else. [They know] very little of the Gambia, and they don't respect it, they don't. Theirs is basically 90 per cent their mother's culture, nothing else. ... There's a clash of cultures: the father wants them to go one way, the mother another, and then. ... The kids are a bit rebellious in the family, you know, and then it's pretty difficult, pretty hard (Alagey, a 46-year-old Gambian married to a Gambian woman, with five children). 
These difficulties, together with the fact that the values the Senegambian fathers want to transmit to their children may come into conflict with the values of their Spanish wives (hierarchy based on age and separation of sexual roles versus more equality in intergenerational dealings and the trend towards equality of roles) may lead to the break-up of the couple. As explained by Lamine, a 40 -yearold Senegambian living in Catalonia since 1985, divorced from a Spanish woman who did not convert to Islam and remarried to a Spanish woman who did:

The first marriage didn't last long. Because after the girl was born ... while she's my responsibility, she has to know where is her Dad from. Why is Dad different from Mum? Why has Dad got that culture and gets up for Ramadan? Those things my kids have got to know, if not their culture gets lost! And the girls are here. ... Donc everything they learn here, that's Spanish culture, that's not their Dad's culture. ... Because she [his ex-wife] said: 'You change or we're through'. I told her: 'I'm not changing, you decide'. ... For her, the girl is Spanish and her mother is Spanish and so she doesn't have to learn anything about African culture. Well, I don't see it that way. ... Here [with his current wife] it's very different from before. She doesn't have ideas like that; she's shown she doesn't mind.

The break-up of mixed couples because of conflicts over gender relations or the raising of children tends to be accompanied by a process of cultural revitalisation. This may result in the formation of a new endogamous union, one which is justified in terms of cultural-religious similarities. As explained by Aliu, a 56-year-old Gambian living in Catalonia since the early 1990s, divorced from a Spanish woman - with whom he has an adolescent son-and remarried to a much younger Gambian woman:

Respect for your parents ... that's very important. Here, it's very different, it's like equals. ... Disobedience, it's not something that we like. We come from a different education. ... And the kids that are born here have other customs. ... I put up with a lot [marriage to his ex-Spanish wife] because we're different, with different customs. We're accustomed to obedience, to obeying the husband, and not to saying: 'Bring me that' and she says 'You get it!' [In the Gambia] the woman is born educated for obedience in marriage; it's not discrimination, it's the way of life we have. The woman is boss of the house. Her happiness, the success of her children, depend on the harmony she has with her husband.

Some would argue that this revitalisation is not caused by a cultural-religious question, but by a desire to maintain certain social privileges. In Malang's words:

For me, those are the false ones; it's the false ones that do it. Because Muslim religion, those that practise it, they don't practise it because they believe in God. ... Me, I see couples here that, like in Africa, I've seen friends that got married and then went, because the Muslim religion is always an instrument for keeping the woman in her place and the man on top. And those people, they do it because then it breeds that mentality in the woman, a woman is like that, with him on top (Malang, a 43-year-old Senegalese married to a Senegalese woman, with two children.

In fact, in the cases analysed, the motive behind endogamous union following the breakdown of a mixed union is more the social differentiation of roles by sex than it is the fact of sharing an affiliation to Islam or country of birth. This alerts us to the culturalisation of gender conflicts (the type of conflicts over gender relations among mixed marriages), as summed up in the following narrative:

When I went to the Mosque in Barcelona, to get classes and so, there are Spanish girls married to African men who got divorced, but wanted to keep on following Islam, so then ... (Pilar, a 32-year-old Spanish woman converted to Islam, married to a Senegalese man with one daughter).

As previously mentioned, Senegambians living in Catalonia tend to live in a situation of transnationality, in which there is a constant flow of contacts, goods and information between the society of origin and the society of immigration. For some of the interviewees, the situation of transmigration means not belonging anywhere: they feel that they belong neither here nor there. In fact, transnationality involves dealing with multiple localisations and cultural backgrounds (here and 
there). For mixed couples with children born and/or brought up in Catalonia, the long-term project might be transnational residency. What is most common is to show children the two realities and let them choose:

If one day I get lucky, my dream is to go with her [his wife] to my country. I don't mean so as to stay there; but if we were retired: here for a while, there for a while. Of course, the difference is, um ... we've lived our lives here now, and having lived here, my children are half from here. So my dream is for them to know both places (Sulayman, 52-year-old Gambian married to a Spanish woman, with three children).

Them [her children], I don't know; they're getting older now, they are grown-up. ... And when they were kids they tended to do what ... they followed their Dad; and what they know and everything comes more from their Dad than from me. But he never stopped me showing them my things. ... Because we've never tried ... I mean: 'you've got to be this or that'. We've taught them and now it's up to them to choose what they want; when they're grown-up let them choose what they want (Gloria, a 52-yearold Spanish woman, married to a Gambian, with three children).

Mercé: You try to go to the [African] parties, so the kids can see something of his culture and all.

SulaymanGe: Traditions and all that, it gets lost with the parents. If you don't show them the way, you don't tell them what there is, of course it gets lost. Of course, they are in another culture that is different from yours; so you have to fight to show them the way, tell them about it. And from time to time, when you can, you bring them there [to the Gambia] so they see it. I don't mean so that they stay, but you can be there for a month or two on holiday so that they see the family, get to know them too.

(Mercé, a 37-year-old Spanish woman and SulaymanGe, a 43-year-old Gambian man, married, with two children).

A priority is that the children be educated in Catalonia, as that will provide them with greater resources for social mobility. Work and health conditions in Senegambia are also considered to be problematic by Spanish spouses:

For me the most important thing is public health. ... I would go [to the Gambia] blindly, provided that the public health system would be more. ... In fact we were about to go! We haven't yet because we thought: 'Now this one [their 13-year-old daughter] with diabetes', it's scary to go there. And also the education issue (Imma, a 36-year-old Spanish woman married to Gambian man, with five children).

In any case, in mixed couples, the Senegambian spouses tend to reiterate their desire to 'leave the door open' for transnational residence for their children in the future or even an eventual more or less permanent emigration. As explained by Lamine and Pilar, a 40-year-old Senegalese living in Catalonia since 1985, cohabiting with a 32-year-old Spanish woman, with one child:

Pilar: Studying, for the future, all that has to be here.

Lamine: I'm not going to send my kid to study there when I'm not there ... at least until he's grown-up; and then ... [laughing] if he wants to go and live in Miami or in. ... When he's grown up, it won't be my responsibility, he can live where he wants. I'm free, I decided to live here because I wanted to. He'll live where he wants and do what he wants; I just want to give him every opportunity, which I didn't have when I was a kid.

The children themselves, born and/or brought up in Catalonia, rarely fulfil the expectations of their parents. They tend to identify themselves primarily as Catalan or Spanish. ${ }^{20}$ But they may also accommodate multi-positional senses of belonging. Moreover, a stronger sense of connection to the country of origin of their Senegambian parents may occur amongst those in families facing economic

\footnotetext{
${ }^{20}$ Tizard and Phoenix (2002: 131-6), for example, found little 'loyalty' to African Caribbean or African origins amongst children of mixed parentage in Britain.
} 
and social difficulties or who may be more closely connected with the society of origin, especially if, in addition to the education attainments obtained in Spain, children can enjoy privileges of ethnic community attachment. As explained by Jeuru, a 41-year-old Gambian who arrived in Spain in 1977, and Maria José, a 37-year-old Spanish woman, married and with three teenage children, all living in a precarious socio-economic situation in a small, isolated rural village in Catalonia:

Jeuru: I tell to them: 'here, if you want to work for the Government, it's very difficult; but in the Gambia, with your surname. ... I phone my uncle, who works in the Government, and that's it!' [when asking their oldest son if he wants to go to the Gambia, while looking at a map of the country, he responds: 'Of course I want to go!'].

MJ: If it wasn't because of the circumstances, we wouldn't be here. It's not that we don't want to go to the Gambia, rather the opposite.

Finally, racism, xenophobia and marginalisation-and in general the hostility of the surrounding environment-can all contribute to processes of ethnic resilience or 'in-group reaction', and to the will to seek better opportunities beyond Spain, including the possibility of emigrating to the country of origin of their parents to form a family there, but also, for some, the desire to migrate elsewhere. ${ }^{21}$

\section{Conclusions}

In this article, I have argued that, despite the predominance of endogamy which is due to structural, normative and preferential causes, a consequence of the permanent settlement of Senegalese and Gambian immigrants in Catalonia is the growing number of mixed marriages and the subsequent formation of transnational families. Further, the context of the formation and the dynamics of mixed unions constitutes a particularly active and complex socio-cultural hybrid space, especially with respect to the upbringing of children. These dynamics involve negotiating and accommodating multiple socio-cultural contexts.

In line with other research (Breger and Hill 1998; Fu 2001; Kalmijn 1998; Noiriel 1996), the evidence shown here suggests the importance of social factors in shaping processes of hybridity. Social class seems a more important factor than cultural origins in determining patterns of endogamy and exogamy, not to mention the dynamics of living together and the raising of mixed-union children. My research reveals that, although often seen in terms of a 'cultural incompatibility', which can lead to a 'clash of civilisations' discourse, the conflicts that arise are due more to socio-economic, situational and personal factors than cultural differences, or at least to a combination of factors, and point to the need for an argument to counter culturalists' explanations which favour processes of essentialisation (Werbner and Modood 1997). Such an argument can be applied, for example, to the culturalisation of gender conflicts, as has been pointed out in earlier studies (see, for instance, Lauth Bacas 2002: 10). In other words, social actors as active subjects, rather than cultures as whole hardened fixed entities, are the main protagonists in processes of socio-cultural transmission and adaptation.

I have emphasised that intermarrying and bringing up children in Senegambian-Spanish couples necessitate dealing with multiple localisations (here and there), a process that involves accommodating hyphenated senses of belonging. Mahtani's (2002) work on 'mixed-race' women in Toronto and Ifekwunigwe's (1999) analysis of working-class and middle-class 'mixed-race' ('black' and 'white') people in England, for instance, suggests that the experiences of the descendants of immigrants and visible minorities challenge the perceptions of 'race', origin, nation and gender, and

\footnotetext{
${ }^{21}$ Likewise, Andall's (2002) analysis of young African-Italians in Milan, for example, suggests that racism and discrimination can contribute to ethnic revitalisation and the articulation of a desire to seek better opportunities beyond Italy.
} 
allow building an argument for the celebration of complex affiliations based on multi-ethnicities and transnationalities (see also Modood 2003). Then again, one should take into consideration the importance of social context. As Rumbaut (1994: 754) reminds us, ethnic self-awareness can be subdued or enhanced 'depending on the degree of dissonance or consonance of the social contexts which are basic to identity formation'. Indeed, the various possible degrees of multi-positionality will depend on the social and political context and the particular socio-economic situation. On the one hand, social and cultural capital are essential factors for effective integration (biculturalism) of immigrants and children of immigrants (Nauck 2001). On the other hand, it would be a mistake to pretend that multicultural links cannot be revitalised. The evidence presented reveals that it might be important to the children's successful adaptation that they maintain 'bi-cultural competencies', not only to avoid the development of anomic personalities but also to take full advantage of the opportunities available, as pointed out by earlier studies (see, for instance, Suárez-Orozco and Suárez-Orozco 2001: 7-9, 60-1, for 'Mexican-immigrants' and 'Mexican-Americans' in the United States).

As has been argued, unfavourable contexts, such as socio-economic instability and discrimination, can lead to 'ingroup' reactions. But it is not necessary to be left out in order to experience ethnic revitalisation. It should be kept in mind that responses concerning the behaviour and identity processes of the descendants of immigrants are neither static nor unique, but rather are constantly negotiated, multi-directional and segmented, as suggested by Suárez-Orozco and Suárez-Orozco (2001), Varro (1995), and Zhou (1997).

Finally, this article has argued against a naïve interpretation of procesess of hybridity, showing the necessity of analysing interculturalism from a perspective that considers it a space in which hybridity and segregation, globalisation and localisation, change and retention are reversible and complementary, rather than competing. One should not make a priori assumptions about the goodness or malice of the different options with regard to processes of endogamy and exogamy, and one should bear in mind that the demands of social integration refer to access, in conditions of equality, to the rights of citizenship. Social class and citizenship dimensions are, therefore, crucial axes.

This research gives rise to a number of questions which call for further investigation, combining large-scale data with fieldwork and intergenerational analysis amongst different immigrant groups, taking into account differences in origin, socio-economic profile and structural organisation. The relationship between patterns of endogamy and exogamy and social mobility, as well as the analysis of intergenerational dynamics and the negotiation of multiple identities as a result of the culturally and/or racially diverse family backgrounds also warrant special attention as a growing phenomenon in Spain (and Southern Europe in general) with important public and political implications. 


\section{References}

Alba, R. and Nee, V. (1997) 'Rethinking assimilation theory for a new era of immigration', International Migration Review, 31(4): 826-75.

Alba, R. and Nee, V. (2003) Remaking the American Mainstream: Assimilation and Contemporary Immigration. Cambridge: Harvard University Press.

Andall, J. (2002) 'Second-generation attitude? African-Italians in Milan', Journal of Ethnic and Migration Studies, 28(3): 389-407.

Banton, M. (1955) The Coloured Quarter: Negro Immigrants in an English City. London: Jonathan Cape.

Bastide, R. (1961) 'Dusky Venus, Black Apollo', Race, 3(1): 10-18.

Bauböck, R. (1996) 'Social and cultural integration in a civil society', in Bauböck, R., Heller, A. and Zolberg, A.R. (eds) The Challenge of Diversity. Integration and Pluralism in Societies of Immigration. Vienna: Avebury, 67-133.

Bhabha, H.K. (1994) The Location of Culture. London: Routledge.

Brah, A. (1996) Cartographies of Diaspora. Contesting Identities. London: Routledge.

Breger, R. and Hill, R. (1998) 'Introducing mixed marriages', in Breger, R. and Hill, R. (eds) CrossCultural Marriage. Identity and Choice. Oxford: Berg, 1-32.

Brubaker, R. (2001) 'The return of assimilation? Changing perspectives on immigration and its sequels in France, Germany, and the United States', Ethnic and Racial Studies, 24(4): 531-48.

Cabré, A. (1999) El Sistema Català de Reproducció (The Catalan System of Reproduction). Barcelona: Institut Català de la Mediterrània.

Calvo Buezas, T. (2000) Inmigración y Racismo. Así sienten los jóvenes del siglo XXI. Madrid: Cauce.

Castles, S. and Davidson, A. (2000) Citizenship and Migration: Globalization and the Politics of Belonging. Basingstoke: Macmillan.

Coleman, D.A. (1983) 'The demography of ethnic minorities', Journal of Biosocial Science, Supplement No. 8: 43-87.

Coleman, D.A. (1994) 'Trends in fertility and intermarriage among immigrant populations in Western Europe as measures of integration', Journal of Biosocial Science, 26(1): 107-36.

EFE (2004) 'Pujol dice que el mestizaje sería el final de Cataluña', El Mundo-Web, 23 August. Online at http://www.elmundo.es/elmundo/2004/08/23/espana/1093277909.html

Favell, A. and Geddes, A. (1999) The Politics of Belonging: Migrants and Minorities in Contemporary Europe. Aldershot: Ashgate.

Fu, V.K. (2001) 'Racial intermarriage pairings', Demography, 38(2): 147-59.

Fundació Jaume Bofill (2005) La immigració a Catalunya avui. Anuari 2004. Barcelona: Mediterrània.

García Canclini, N. (1995) Hybrid Cultures: Strategies for Entering and Leaving Modernity. Minneapolis: University of Minnessota Press.

Geanâ, G. (1997) 'Ethnicity and globalisation. Outline of a complementarist conceptualisation', Social Anthropology, 5(2): 197-209.

Generalitat de Catalunya (2005) Pla de Ciutadania i Immigració 2005-2008 (Plan of Citizenship and Immigration 2005-2008, Autonomous Government of Catalonia), Departament de Benestar i Familia, Secretaria per a la Immigració. Online at www.gencat.net/benestar/societat/convivencia/immigracio/pla/introduccio/index.htm

Glick Schiller, N., Basch, L. and Blanc-Szanton, C. (1995) 'From immigrant to transmigrant: theorising transnational migration', Anthropological Quarterly, 68(1): 48-54.

Gordon, M. (1964) Assimilation in American Life: The Role of Race, Religion, and National Origins. New York: Oxford University Press.

Gray, A. (1987) 'Intermarriage: opportunity and preference', Population Studies, 41(3): 365-79.

Grillo, R.D., Riccio, B. and Salih, R. (2000) Here or There?. Contrasting Experiences of Transnationalism: Moroccans and Senegalese in Italy. Brighton: University of Sussex, Centre for Culture, Development and Environment. 
Herrscher, R. and Merino, F. (1999) 'Amor de colores. Las parejas de distinta etnia se multiplican en Cataluña' (Love in colours. Rise of interethnic couples in Catalonia). El Periódico, Sunday Special, 2-7, 3 October 1999.

Home Affairs Ministry (2003a) Anuario Estadístico de Extranjería 2003 (Statistical Yearbook of Foreigners, 2003). Madrid: Delegación del Gobierno para la Extranjería y la Inmigración, Observatorio Permanente de la Inmigración. http://extranjeros.mtas.es/es/general/DatosEstadisticos_index.html

Home Affairs Ministry (2003b) Ley Orgánica 4/2000 sobre derechos y libertades de los extranjeros en españa y su integración social (modified by the Ley Orgánica 8/2000 and the Ley Orgánica 14/2003). http://www.igsap.map.es/cia/dispo/17877.htm

Ifekwunigwe, J. (1999) Scattered Belongings: Cultural Paradoxes of 'Race', Nation and Gender. London: Routledge.

INE (National Institute of Statistics) (2005a) Notas de Prensa: Movimiento Natural de la Población. Press release, 22 June 2005, online at http://www.ine.es/prensa/np376.pdf

INE (National Institute of Statistics) (2005b) Padrón Municipal de Población. Online at www.ine.es

Kalmijn, M. (1998) 'Intermarriage and homogamy: causes, patterns and trends', Annual Review of Sociology, 24: 395-421.

Kaplan, A. (1998) De Senegambia a Cataluña: procesos de aculturación e integración social. Barcelona: Fundació La Caixa.

Kim, K.C. and Hurh, W.M. (1993) 'Beyond assimilation and pluralism: syncretic socio-cultural adaptation of korean immigrants in the US', Ethnic and Racial Studies, 14(4): 696-712.

King, R. (ed.) (2001) The Mediterranean Passage. Migration and New Cultural Encounters in Southern Europe. Liverpool: Liverpool University Press.

Lauth Bacas, J. (2002) Cross-Border Marriages and the Formation of Transnational Families: A Case Study of Greek-German Couples in Athens. Oxford: University of Oxford, Working Paper online at www.transcomm.ox.ac.uk/working\%20papers/WPTC-02-10\%20Bacas.pdf

Lievens, J. (1999) 'Family-forming migration from Turkey and Morocco to Belgium: the demand for marriage partners from the countries of origin', International Migration Review, 33(3): 717-44.

Mahtani, M. (2002) Interrogating the Hyphen-Nation: Canadian Multicultural Policy and 'Mixed Race' Identities. Toronto: CERIS Working Paper No. 20, October 2002.

Marshall, T.H. (1950) Citizenship and Social Class. Cambridge: Cambridge University Press.

McDaniel, S.A. and Tepperman, L. (2000) Close Relations. An Introduction to the Sociology of Families. Scarborough, Ontario: Prentice-Hall.

Merton, R.K. (1941) 'Intermarriage and the social structure: fact and theory', Psychiatry, 4: 361-74.

Meyer, B. and Gestchiere, P. (eds) (1999) Globalization and Identity: Dialectics of Flow and Closure. Oxford: Blackwell.

Miles, R. (1993) Racism after 'Race Relations'. London and New York: Routledge.

Modood, T. (2003) 'New forms of Britishness: post-immigration ethnicity and hybridity in Britain', in Sackmann, R., Peters, B. and Faist, T. (eds) Identity and Integration. Migrants in Western Europe. Aldershot: Ashgate, 77-90.

Murstein, B.I. (1986) Paths to Marriage. London: Sage.

Musham, H.V. (1974) 'The marriage squeeze', Demography, 11(2): 291-9.

Myles, J. and Hou, F. (2002) Changing Colours: Neighborhood Attainment and Residential Segregation Among Toronto's Visible Minorities. Toronto: University of Toronto. Online at www.utoronto.ca/ethnicstudies/Myles_paper.pdf

Nauck, B. (2001) 'Social capital, intergenerational transmission and intercultural contact in immigrant families', Journal of Comparative Family Studies, 32(4): 465-88.

Noiriel, G. (1996) The French Melting Pot. Immigration, Citizenship and National Identity. Minneapolis and London: University of Minessota Press.

Olumide, J. (2002) Raiding the Gene Pool. The Social Construction of Mixed Race. London: Pluto Press. 
Phoenix, A. and Owen, C. (2000) 'From miscegenation to hybridity: mixed relationships and mixed parentage in profile', in Brah, A. and Coombes, A. (eds) Hybridity and its Discontents. Politics, Science, Culture. London and New York: Routledge, 72-95.

Portes, A. and Zhou, M. (1993) 'The new second generation: segmented assimilation and its variants among post-1965 immigrant youth', The Annals, 530: 74-96.

Portes, A. and Zhou, M. (1994) 'Should immigrants assimilate?', The Public Interest, 116: 18-33.

Portes, A., Guarnizo, L. and Landolt, P. (eds) (1999) Transnational Communities. Special issue of Ethnic and Racial Studies, 22(2).

Richmond, A.H. (1988) 'Socio-cultural adaptation and conflict in immigrant-receiving countries', in Stahl, C. (ed.) International Migration Today. Vol. 2. Emerging Issues. Perth: UNESCO-University of Western Australia, Centre for Migration and Development Studies, 109-24.

Rodríguez García, D. (2002) Endogamy, Exogamy and Interethnic Relations. An Analysis of the Processes of Mate Choice and Family Formation among Senegalese and Gambian Immigrants in Catalonia, Spain (in Spanish). Barcelona: Universitat Autònoma de Barcelona, unpublished PhD thesis, online at: www.tdx.cesca.es/TDCat-0223103-184400/

Rodríguez García, D. (2004) Inmigración y Mestizaje Hoy. Formación de matrimonies mixtos y familias transnacionales de población Africana en Cataluña (Immigration and Hybridity Today. The Formation of Mixed Marriages and Transnational Families of African Migrants in Catalonia). Bellaterra: Universitat Autònoma de Barcelona, Servei de Publicacions.

Rodríguez, F. (1999) Miedo en Ca n'Anglada. Más incidentes racistas en Terrassa, donde los magrebies no salen de sus casas (Concern in Ca n'Anglada. More racists episodes in Terrassa, where North-Africans stay in their houses). La Vanguardia-Web Edition, 16/07/1999.

Root, M. (ed.) (1996) The Multiracial Experience: Racial Borders as the New Frontier. London: Sage.

Rumbaut, R. (1994) 'The crucible within: ethnic identity, self-steem, and segmented assimilation among children of immigrants', International Migration Review, 28(4): 748-94.

Rumbaut, R. and Portes, A. (2001) Ethnicities: Children of Immigrants in America. Berkeley: University of California Press.

SOPEMI (2004) Trends in International Migration. Annual Report 2004. Paris: OECD.

Stark, O. (1988) 'On marriage and migration', European Journal of Population, 4(1): 23-37.

Suárez-Orozco, C. and Suárez-Orozco, M. (2001) Children of Immigration. Cambridge: Harvard University Press.

Tizard, B. and Phoenix, A. (2002) Black, White or Mixed Race?. Race and Racism in the Lives of Young People of Mixed Parentage. London and New York: Routledge.

Todd, E. (1994) Le Destin des Immigrés. Assimilation et ségrégation dans les démocraties occidentales. Paris: Seuil.

Vandellós, J.A. (1935) La Immigració a Catalunya. Barcelona: Institució Patxot.

Varro, G. (1995) Les Couples Mixtes et Leurs Enfants en France et en Allemagne. Paris: Armand Colin.

Vertovec, S. and Cohen, R. (1999) Migration, Diasporas and Transnationalism. Cheltenham: Edward Elgar.

Vicent, M. (2001) 'Pasaporte conyugal. Se dispara el número de matrimonios hispano-cubanos para conseguir un visado' (Conjugal Passport. A shoot up of Spaniard-Cuban marriages to obtain a visa), El País, 22 July 2001, p. 5.

Werbner, P. and Modood, T. (eds) (1997) Debating Cultural Hybridity. Multicultural Identity and the Politics of Anti-Racism. London: Zed Books.

Winch, R.F. (1958) Mate Selection: A Study of Complementary Needs. New York: Harper.

Zapata-Barrero, R. (2003) 'Spain', in Niessen, J., Schibel, Y. and Magoni, R. (eds) EU and US Approaches to the Management of Immigration. Brussels: MPG, 459-89.

Zhou, M. (1997) 'Segmented assimilation: issues, controversies, and recent research on the new second generation', International Migration Review, 31(4): 975-1008. 